\title{
Lower extremity and spine pain in cyclists
}

\author{
Sylwia Ewa Piotrowska', Marian Majchrzycki², Piotr Rogala', Martyna Mazurek-Sitarz ${ }^{3,4}$ \\ ${ }^{1}$ Department of Spine Surgery, Oncologic Orthopaedics and Traumatology, University of Medical Sciences, Poznan, Poland \\ ${ }^{2}$ Department of Rheumatology and Rehabilitation, University of Medical Sciences, Poznan, Poland \\ ${ }^{3}$ Institute of Rural Health in Lublin, Lublin, Poland \\ ${ }^{4}$ Chair of Rehabilitation, Physiotherapy and Balneotherapy Medical University, Lublin, Poland
}

Piotrowska S. E, Majchrzycki M, Rogala P, Mazurek-Sitarz M. Lower extremity and spine pain in cyclists. Ann Agric Environ Med. 2017; 24(4): 654-658. doi: 10.5604/12321966.1233552

\section{Abstract}

Introduction. The number of cyclists increases each year. Some people treat cycling as a passion and practice it at every possible occasion, while for others it is a mean of transport or a form of relaxation at the weekend. However, very few people realize that cycling can also have a negative impact on their health.

Objective. To assess the prevalence of lower extremity and spine pain in cyclists, and evaluate the influence of various factors causing it.

Materials and method. The study was performed on 167 subjects during amateur cycling competitions in the Greater Poland and Kuyavian-Pomeranian Provinces. A specially prepared questionnaire was used in the study. The questions related to the pain caused by cycling, the character and the localization of the pain, and the presence of warm-up and stretching. Results. Knee pain was reported in $40 \%$ of the study subjects (mostly anterior pain - 26\%). Spine pain was reported in $41 \%$ of the studied athletes, where $26 \%$ was related with the lumbar spine. Variables, such as age, weight, age, BMI, training experience and number of hours devoted to training per week had no influence on the incidence and the localization of leg pain, but it had influence in the case of spine pain. Stretching after cycling was the factor which significantly distinguished the studied groups with regard to the incidence of knee pain.

Conclusions. The most common type of leg pain was knee pain (anterior knee pain) whereas spine pain was most commonly reported in the lumbar spine. Statistical analysis showed that spine pain is more often reported by people who are older, have higher weight, and people who spend more time training per week. Warm-up and stretching after cycling are recommended to cyclists who experience pain.

\section{Key words}

cycling- injuries, lower extremity, spine

\section{INTRODUCTION}

Physical activity is a factor affecting the quality of life and longevity by, for example, recuing the risk of obesity, metabolic syndrome [1], and cancer [2]. One of the most commonly practiced forms of physical activity by society at large is cycling [3]. The Polish Central Statistical Office (Główny Urząd Statystyczny - GUS) states that approximately 55\% of household members ride a bicycle [3]. These numbers are subject to changes with each year. The increasing number of cyclists is associated with the increasing number of injuries.

Cycling is considered a non-impact sport, in which the body of the cyclist is constantly affected by vibration $[4,5]$. Injuries in cyclists are divided into acute trauma (caused by a fall, traffic accident, or using improper bicycle equipment) and chronic overuse injuries $[6,7,8]$. Overuse injuries occur in bicycle riders who regularly ride their bicycle $[7,9]$. Overuse and acute injuries can be caused by unsuitable preparation for cycling (lack of warm-up, use of wrong equipment), poor riding technique, including inappropriate body position $[10,11,12,13]$. The nature of the terrain used for riding a bicycle also affects the injury incidence (falling from a bicycle, vibration) $[4,7]$. Overuse injuries are more common than acute traumas in mountain bikers who ride on mixed terrain $[7,12]$.

Address for correspondence: Sylwia Ewa Piotrowska, Department of Spine Surgery, Oncologic Orthopaedics and Traumatology, Poznan University of Medical Sciences, 28 Czerwca 1956 roku 135/147, 61-545 Poznan, Poland

E-mail: sylwia.piotrowskaa@gmail.com

Receivd: 22 July 2014; accepted: 29 October 2014; first published on February 2017

\section{OBJECTIVE}

The purpose of this study is to assess the incidence of pain in the lower extremities and spine caused by riding a bicycle, and to evaluate the influence of various factors (such as age, weight, training experience, presence of warm-up/stretching) on injury incidence.

\section{MATERIALS AND METHOD}

167 people from different parts of Poland participated in the study. Only amateur cyclists participating in competitive racing (March 2013 - October 2013) were included. Detailed inclusion and exclusion criteria are presented in Table 1.

The studied group was selected randomly from the participants in amateur mountain bicycle racing competitions held on very mixed terrain. The nature of the terrain ranged from sandy field roads, through forest paths with visible tree roots, to difficult rocky slopes.

The study used a specially prepared questionnaire consisting of single-choice and multiple-choice close-ended questions. The questions sought to:

a) establish the prevalence of lower extremity and spine injury within a sample group of cyclists;

b) identify the most common location of lower extremity and spine pain;

c) show the type of warm-up performed by the cyclists;

d)investigate the relationship between the incidence of lower extremity and spine pain and the presence of warm-up. 
Table 1. Inclusion and exclusion criteria used in the study

\begin{tabular}{ll}
\hline Inclusion criteria & Exclusion criteria \\
\hline - people training for and participating in competitive racing on mixed terrain & - people participating in competitive racing sporadically \\
\hline - people riding mountain or cyclocross bicycles & - people training on highways \\
\hline - people actively training/racing on bicycles for at least one year & - people riding bicycles other than mountain or cyclocross bikes, e.g. roadster bicycles \\
\hline - when injury/pain occurred, sustained between 2010-2013 & - people who intensively train in other sports (swimming, running, basketball etc.) \\
\hline
\end{tabular}

Regarding the location of the injury, the interviewer also asked cyclists to indicate the location of pain on a diagram of human body (view from front, back, side).

The following definition of injury was used in the study: any musculoskeletal ailment that caused the athlete to reduce or refrain from, training for at least two days during the period 2010-2013.

Detailed characteristics of the participants are shown in Table 2.

Table 2. Data characterizing all participants (mean \pm SD, maximum and minimum value, normal distribution)

\begin{tabular}{lcccc}
\hline & Mean \pm SD & Minimum & Maximum & $\begin{array}{c}\text { Normal } \\
\text { distribution* }(\mathrm{P})\end{array}$ \\
\hline age $\pm \mathrm{SD}[\mathrm{y}]$ & $30.98 \pm 8.02$ & 15 & 56 & $P=0,0033$ \\
\hline weight \pm SD $[\mathrm{kg}]$ & $74.87 \pm 9.46$ & 54 & 110 & $P<0,0001$ \\
\hline height \pm SD [m] & $1.79 \pm 0.066$ & 1.63 & 2.00 & $P=0,6780$ \\
\hline BMl \pm SD [kg] & $23.32 \pm 2.51$ & 18.63 & 33.95 & $P<0,0001$ \\
\hline training \pm SD [h/week] & $11.78 \pm 6.89$ & 2 & 50 & $P<0,0001$ \\
\hline training experience [y] & $7.16 \pm 6.74$ & 1 & 50 & $P<0,0001$ \\
\hline
\end{tabular}

*verified through Shapiro-Wilk test

Quantitative Traits of the study subjects were described with basic statistics using minimum value, maximum value, mean value and standard deviation (SD). The Shapiro-Wilk test was used to evaluate the similarity of distribution of variables (age, weight, BMI, training experience and number of hours devoted to training per week) to normal distribution. The selection of methods and tests used in the analysis depended on the spread of results and their associations. The Mann-Whitney $U$ test and Fisher's exact test were used to compare two independent groups. A 95\% confidence interval was adopted in the calculations. The results were developed using statistical software STATISTICA 10 (StatSoft, Poland).

\section{RESULTS}

Pain in lower extremities and spine. The collected data showed that leg pain and spine pain was experienced by 72 and 70 subjects respectively. Knee joint pain (40\%) and lumbar spine pain (33\%) were the most common (Tab. 3). The least reported lower extremity pain was hip joint pain $(9.6 \%)$, and the least reported spine pain was in the thoracic spine pain $(5.4 \%)$.

Thanks to precise descriptions of the localization of pain by the study subjects a more detailed distribution of knee joint pain was available in 4 surfaces. The most common localization of knee joint pain in all studied subjects was the anterior surface of the joint (26\%). Lateral knee pain was reported in $12 \%$ of subjects and medial knee pain in $13 \%$
Table 3. Incidence of pain in lower extremity joints and spine

\begin{tabular}{|c|c|c|c|c|c|c|c|c|}
\hline & & \multicolumn{3}{|c|}{ LOWER EXTREMITY } & \multicolumn{4}{|c|}{ SPINE } \\
\hline & & $\begin{array}{l}\text { Hip } \\
\text { joint }\end{array}$ & $\begin{array}{l}\text { Knee } \\
\text { joint }\end{array}$ & $\begin{array}{c}\text { Ankle } \\
\text { joint }\end{array}$ & $\begin{array}{c}\text { Cervical } \\
\text { curve }\end{array}$ & $\begin{array}{c}\text { Thoracic } \\
\text { curve }\end{array}$ & $\begin{array}{c}\text { Lumbar } \\
\text { curve }\end{array}$ & $\begin{array}{l}\text { Sacral } \\
\text { curve }\end{array}$ \\
\hline \multirow{2}{*}{$\begin{array}{l}\text { Pain } \\
\text { occurance }\end{array}$} & YES & 16 & 66 & 17 & 19 & 9 & 55 & 20 \\
\hline & NO & 151 & 101 & 150 & 148 & 157 & 112 & 147 \\
\hline
\end{tabular}

of subjects. Anterior knee joint pain was the least common (4.8\%).

Age, weight, height, BMI, time spent on a bicycle and the lower extremity pain. In order to examine the relationship between age, weight, height, BMI, time spent on a bicycle and the presence of pain in a given body region, the study subjects were divided into 2 groups - subjects with pain and subjects with no pain in a given body region. The analysis was performed using the Mann-Whitney $U$ test $(\alpha=0.05)$. Before each analysis, normal distribution was checked for every group (Shapiro-Wilk test, $\alpha=0.05$ ).

There was no significant effect of any of the studied factors on the incidence of lower extremity pain (Tab. 4).

Table 4. Effect of various factors on the incidence of lower extremity pain

\begin{tabular}{lccc}
\hline & Hip joint & Knee joint & Ankle joint \\
\hline Age & $P=0,3735$ & $P=0,9699$ & $P=0,9177$ \\
\hline Weight & $P=0,9956$ & $P=0,6640$ & $P=0,4374$ \\
\hline Height & $P=0,1768$ & $P=0,1610$ & $P=0,4437$ \\
\hline BMl & $P=0,3638$ & $P=0,9817$ & $P=0,2368$ \\
\hline Training experience & $P=0,4080$ & $P=0,7295$ & $P=0,5200$ \\
\hline Trainings per week & $P=0,5289$ & $P=0,7647$ & $P=0,1500$
\end{tabular}

Age, weight, height, BMI, time spent on a bicycle and spine pine. Analysis showed that older people are more likely to report lumbar spine pain. Cervical spine pain is more often reported by people with height and weight above the average. Significant differences between the groups were also found in the relationship between BMI and training experience and thoracic spine pain. Sacral spine pain was reported more frequently by people who spent more hours per week training.

Warm-up and stretching after cycling. 155 athletes declared they performed warm-up, and 12 people declared the opposite. The group performing warm-up (always, often, sometimes, only before competitions) was not significantly (statistically speaking) different, in terms of pain incidence, from the group performing no warm-up (Fisher's exact test: $\mathrm{p}>0.05$ ).

It was established that the most common form of warm-up was calm cycling. Approximately $48 \%$ of cyclists spent 5-15 minutes on this type of warm-up, and approximately $35 \%$ 
Table 5. The effect of various factors on the incidence of spine pain

\begin{tabular}{lcccc}
\hline & $\begin{array}{c}\text { Cervical } \\
\text { curve }\end{array}$ & $\begin{array}{c}\text { Thoracic } \\
\text { curve }\end{array}$ & $\begin{array}{c}\text { Lumbar } \\
\text { curve }\end{array}$ & $\begin{array}{c}\text { Sacral } \\
\text { curve }\end{array}$ \\
\hline Age & $P=0,7525$ & $P=0,5679$ & $\boldsymbol{P}=\mathbf{0 , 0 3 0 8 *}$ & $P=0,4371$ \\
\hline Weight & $\boldsymbol{P}=\mathbf{0 , 0 1 9 2 *}$ & $P=0,2038$ & $P=0,0056$ & $P=0,5242$ \\
\hline Height & $\boldsymbol{P}=\mathbf{0 , 0 1 9 3 *}$ & $P=0,0884$ & $P=0,6282$ & $P=0,7746$ \\
\hline BMl & $P=0,2322$ & $\boldsymbol{P}=\mathbf{0 , 0 0 9 1 *}$ & $P=0,0065$ & $P=0.7599$ \\
\hline Training experience & $P=0,4962$ & $\boldsymbol{P}=\mathbf{0 , 0 4 9 2 *}$ & $P=0,9848$ & $P=0,6974$ \\
\hline Trainings per week & $P=0,5937$ & $P=0,4343$ & $P=0,7348$ & $\boldsymbol{P}=\mathbf{0 , 0 4 5 6 *}$ \\
\hline
\end{tabular}

* statistically significant results (the Mann-Whitney $U$ test, $a=0.05$ )

Table 6. Relationship between incidence of lower extremity and spine pain, and presence of warm-up

\begin{tabular}{cccccc}
\hline & & \multicolumn{2}{c}{ Lower extremity pain } & \multicolumn{2}{c}{ Spine pain } \\
\cline { 2 - 6 } & YES $(n=72)$ & NO $(n=95)$ & YES $(n=70)$ & NO $(n=97)$ \\
\hline \multirow{4}{*}{ Warm-up } & YES $(n=155)$ & $\begin{array}{c}67 \\
(93.06 \%)\end{array}$ & $\begin{array}{c}88 \\
(92.63 \%)\end{array}$ & $\begin{array}{c}67 \\
(95.71 \%)\end{array}$ & $\begin{array}{c}88 \\
(90.72 \%)\end{array}$ \\
\cline { 2 - 6 } & NO (n=12) & 5 & 7 & 3 & 9 \\
& $(6.94 \%)$ & $(7.37 \%)$ & $(4.29 \%)$ & $(9.28 \%)$ \\
\hline
\end{tabular}

Table 7. Type of exercises performed by the athletes

\begin{tabular}{lccc}
\hline Duration & Calm cycling & Static exercises & Massage \\
\hline $0-5 \mathrm{~min}$ & 13 & 35 & 8 \\
\hline $5-15 \mathrm{~min}$ & 80 & 15 & 4 \\
\hline $15-30 \mathrm{~min}$ & 58 & 1 & 1 \\
\hline$>30 \mathrm{~min}$ & 8 & - & 1 \\
\hline TOTAL & $\mathbf{1 5 9}$ & $\mathbf{5 1}$ & $\mathbf{1 4}$ \\
\hline
\end{tabular}

Table 8. Frequency of warm-up and stretching after cycling performer by the athletes

\begin{tabular}{|c|c|c|c|c|c|c|c|c|c|c|c|c|c|c|c|}
\hline & & \multicolumn{14}{|c|}{ PAIN AND ITS LOCALIZATION } \\
\hline & & \multicolumn{2}{|c|}{ hip joint } & \multicolumn{2}{|c|}{ knee joint } & \multicolumn{2}{|c|}{ ankle joint } & \multicolumn{2}{|c|}{ cervical curve } & \multicolumn{2}{|c|}{ thoracic curve } & \multicolumn{2}{|c|}{ lumbar curve } & \multicolumn{2}{|c|}{ sacral curve } \\
\hline \multicolumn{2}{|c|}{ Factor } & YES & NO & YES & NO & YES & NO & YES & NO & YES & NO & YES & NO & YES & NO \\
\hline \multirow{6}{*}{ 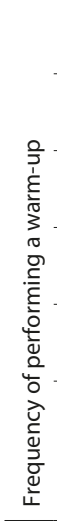 } & always & $\begin{array}{c}8 \\
(50 \%)\end{array}$ & $\begin{array}{c}74 \\
(49.01 \%)\end{array}$ & $\begin{array}{c}34 \\
(51.52 \%)\end{array}$ & $\begin{array}{c}48 \\
(47.52 \%)\end{array}$ & $\begin{array}{c}10 \\
(58.82 \%)\end{array}$ & $\begin{array}{c}72 \\
(48 \%)\end{array}$ & $\begin{array}{c}8 \\
(42.11 \%)\end{array}$ & $\begin{array}{c}74 \\
(50 \%)\end{array}$ & $\begin{array}{c}5 \\
(55.56 \%)\end{array}$ & $\begin{array}{c}77 \\
(48.73 \%)\end{array}$ & $\begin{array}{c}24 \\
(43.64 \%)\end{array}$ & $\begin{array}{c}58 \\
(51.79 \%)\end{array}$ & $\begin{array}{c}8 \\
(40 \%)\end{array}$ & $\begin{array}{c}74 \\
(50.34 \%)\end{array}$ \\
\hline & often & $\begin{array}{c}2 \\
(12.5 \%)\end{array}$ & $\begin{array}{c}23 \\
(15.23 \%) \\
\end{array}$ & $\begin{array}{c}6 \\
(9.09 \%) \\
\end{array}$ & $\begin{array}{c}19 \\
(18.81 \%)\end{array}$ & $\begin{array}{c}1 \\
(5.88 \%)\end{array}$ & $\begin{array}{c}24 \\
(16 \%) \\
\end{array}$ & $\begin{array}{c}3 \\
(15.79 \%) \\
\end{array}$ & $\begin{array}{c}22 \\
(14.86 \%)\end{array}$ & $\begin{array}{c}1 \\
(11.11 \%)\end{array}$ & $\begin{array}{c}24 \\
(15.19 \%)\end{array}$ & $\begin{array}{c}11 \\
(20 \%)\end{array}$ & $\begin{array}{c}14 \\
(12.50 \%)\end{array}$ & $\begin{array}{c}3 \\
(15 \%) \\
\end{array}$ & $\begin{array}{c}22 \\
(14.97 \%) \\
\end{array}$ \\
\hline & sometimes & $\begin{array}{c}3 \\
(18.75 \%)\end{array}$ & $\begin{array}{c}18 \\
(11.92 \%)\end{array}$ & $\begin{array}{c}10 \\
(15.15 \%)\end{array}$ & $\begin{array}{c}11 \\
(10.89 \%)\end{array}$ & $\begin{array}{c}2 \\
(11.76 \%)\end{array}$ & $\begin{array}{c}19 \\
(12.67 \%)\end{array}$ & $\begin{array}{c}4 \\
(21.05 \%)\end{array}$ & $\begin{array}{c}17 \\
(11.49 \%)\end{array}$ & $\begin{array}{c}3 \\
(33.33 \%)\end{array}$ & $\begin{array}{c}18 \\
(11.39 \%)\end{array}$ & $\begin{array}{c}6 \\
(10.91 \%)\end{array}$ & $\begin{array}{c}15 \\
(13.39 \%)\end{array}$ & $\begin{array}{c}5 \\
(25 \%)\end{array}$ & $\begin{array}{c}16 \\
(10.88 \%)\end{array}$ \\
\hline & $\begin{array}{l}\text { only before } \\
\text { competitions }\end{array}$ & $\begin{array}{c}2 \\
(12.5 \%)\end{array}$ & $\begin{array}{c}25 \\
(16.56 \%)\end{array}$ & $\begin{array}{c}11 \\
(16.67 \%)\end{array}$ & $\begin{array}{c}16 \\
(15.84 \%)\end{array}$ & $\begin{array}{c}3 \\
(17.65 \%)\end{array}$ & $\begin{array}{c}24 \\
(16 \%)\end{array}$ & $\begin{array}{c}3 \\
(15.79 \%)\end{array}$ & $\begin{array}{c}24 \\
(16.22 \%)\end{array}$ & $\begin{array}{c}0 \\
(0 \%)\end{array}$ & $\begin{array}{c}27 \\
(17.09 \%)\end{array}$ & $\begin{array}{c}12 \\
(21.82 \%)\end{array}$ & $\begin{array}{c}15 \\
(13.39 \%)\end{array}$ & $\begin{array}{c}2 \\
(10 \%)\end{array}$ & $\begin{array}{c}25 \\
(17.01 \%)\end{array}$ \\
\hline & never & $\begin{array}{c}1 \\
(6.25 \%)\end{array}$ & $\begin{array}{c}11 \\
(7.28 \%)\end{array}$ & $\begin{array}{c}5 \\
(7.58 \%)\end{array}$ & $\begin{array}{c}7 \\
(6.93 \%)\end{array}$ & $\begin{array}{c}1 \\
(5.88 \%)\end{array}$ & $\begin{array}{c}11 \\
(7.33 \%)\end{array}$ & $\begin{array}{c}1 \\
(5.26 \%)\end{array}$ & $\begin{array}{c}11 \\
(7.43 \%)\end{array}$ & $\begin{array}{c}0 \\
(0 \%)\end{array}$ & $\begin{array}{c}12 \\
(7.59 \%)\end{array}$ & $\begin{array}{c}2 \\
(3.64 \%)\end{array}$ & $\begin{array}{c}10 \\
(8.93 \%)\end{array}$ & $\begin{array}{c}2 \\
(10 \%)\end{array}$ & $\begin{array}{c}10 \\
(6.8 \%)\end{array}$ \\
\hline & $\begin{array}{l}\text { Mann- } \\
\text { Whitney } \\
U \text { test results } \\
(P)\end{array}$ & \multicolumn{2}{|c|}{$P=0.8981$} & \multicolumn{2}{|c|}{$P=0.9636$} & \multicolumn{2}{|c|}{$P=0.5941$} & \multicolumn{2}{|c|}{$P=0.6659$} & \multicolumn{2}{|c|}{$P=0.4523$} & \multicolumn{2}{|c|}{$P=0.5706$} & \multicolumn{2}{|c|}{$P=0.4809$} \\
\hline \multirow{4}{*}{ 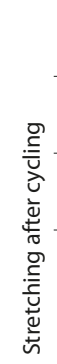 } & yes, always & $\begin{array}{c}8 \\
(50 \%)\end{array}$ & $\begin{array}{c}44 \\
(29.14 \%)\end{array}$ & $\begin{array}{c}28 \\
(42.42 \%)\end{array}$ & $\begin{array}{c}24 \\
(23.76 \%)\end{array}$ & $\begin{array}{c}6 \\
(35.29 \%)\end{array}$ & $\begin{array}{c}46 \\
(30.67 \%)\end{array}$ & $\begin{array}{c}7 \\
(36.84 \%)\end{array}$ & $\begin{array}{c}45 \\
(30.41 \%)\end{array}$ & $\begin{array}{c}4 \\
(44.44 \%)\end{array}$ & $\begin{array}{c}48 \\
(30.38 \%)\end{array}$ & $\begin{array}{c}16 \\
(29.09 \%)\end{array}$ & $\begin{array}{c}36 \\
(32.14 \%)\end{array}$ & $\begin{array}{c}6 \\
(30 \%)\end{array}$ & $\begin{array}{c}46 \\
(31.29 \%)\end{array}$ \\
\hline & $\begin{array}{l}\text { yes, } \\
\text { sometimes }\end{array}$ & $\begin{array}{c}6 \\
(3.59 \%) \\
\end{array}$ & $\begin{array}{c}75 \\
(49.67 \%) \\
\end{array}$ & $\begin{array}{c}29 \\
(43.94 \%)\end{array}$ & $\begin{array}{c}52 \\
(51.49 \%) \\
\end{array}$ & $\begin{array}{c}7 \\
(41.18 \%) \\
\end{array}$ & $\begin{array}{c}74 \\
(49.33 \%) \\
\end{array}$ & $\begin{array}{c}8 \\
(42.11 \%) \\
\end{array}$ & $\begin{array}{c}73 \\
(49.32 \%) \\
\end{array}$ & $\begin{array}{c}4 \\
(44.44 \%) \\
\end{array}$ & $\begin{array}{c}77 \\
(48.73 \%) \\
\end{array}$ & $\begin{array}{c}25 \\
(45.45 \%) \\
\end{array}$ & $\begin{array}{c}56 \\
(50 \%) \\
\end{array}$ & $\begin{array}{c}10 \\
(50 \%)\end{array}$ & $\begin{array}{c}71 \\
(48.30 \%) \\
\end{array}$ \\
\hline & no, never & $\begin{array}{c}2 \\
(12.5 \%)\end{array}$ & $\begin{array}{c}32 \\
(21.19 \%)\end{array}$ & $\begin{array}{c}9 \\
(13.64 \%)\end{array}$ & $\begin{array}{c}25 \\
(24.75 \%)\end{array}$ & $\begin{array}{c}4 \\
(23.53 \%)\end{array}$ & $\begin{array}{c}30 \\
(20 \%)\end{array}$ & $\begin{array}{c}4 \\
(21.05 \%)\end{array}$ & $\begin{array}{c}30 \\
(20.27 \%)\end{array}$ & $\begin{array}{c}1 \\
(11.11 \%)\end{array}$ & $\begin{array}{c}33 \\
(20.89 \%)\end{array}$ & $\begin{array}{c}14 \\
(25.45 \%)\end{array}$ & $\begin{array}{c}20 \\
(17.86 \%)\end{array}$ & $\begin{array}{c}4 \\
(20 \%)\end{array}$ & $\begin{array}{c}30 \\
(20.41 \%)\end{array}$ \\
\hline & $\begin{array}{l}\text { Mann- } \\
\text { Whitney } \\
U \text { test results } \\
(P)\end{array}$ & \multicolumn{2}{|c|}{$P=0.1075$} & \multicolumn{2}{|c|}{$P=0.0077^{*}$} & \multicolumn{2}{|c|}{$P=0.9290$} & \multicolumn{2}{|c|}{$P=0.7260$} & \multicolumn{2}{|c|}{$P=0.3281$} & \multicolumn{2}{|c|}{$P=0.3836$} & \multicolumn{2}{|c|}{$P=0.9552$} \\
\hline
\end{tabular}

*statistically significant results (the Mann-Whitney $U$ test; $\alpha=0.05$ )

spent 15-30 minutes. Static exercises were a less common form of warm-up (approximately 31\%). Massage was used by a small number of cyclists. There was no significant relationship between the groups with regard to the frequency of performing a warm-up and the incidence of pain (Tab. 8) (the Mann-Whitney $U$ test, $\alpha=0.05$ ).

Stretching after cycling was a factor which significantly differentiated the studied groups with regard to the incidence of knee pain (Tab. 8).

\section{DISCUSSION}

The studied subjects participated in mountain cross-country (XC) races and marathons (MX). Cross-country races are characterized by fast, high-intensity cycling for short distances $(4-18 \mathrm{~km})$ [UCI 4.2.002, 4.2.004], in a relatively short period of time (approx. 1-1.5 hours) [UCI 4.2.001]. According to the rules of the Union Cycliste Internationale, a marathon cannot be shorter than 3 hours for the fastest participant and has to be at least $60 \mathrm{~km}$ long [UCI 4.2.004]. It is characterized by a long physical effort spread over time.

Most participants of cycling races are male, with only a small percentage of women taking part in the competitions [14]. In Poland, women constitute approx. $10 \%$ of the total number of competitors [15]. In the presented study, the material consisted only of men due to low female participation in the competitions at the time of the study, and the refusal of female participants to take part in the study. The low number of female participants in mountain cycling competitions, both in XC cycling and marathons, should be attributed to the specificity of routes during competitions. The two types 
of competition are held on the same kind of terrain which ranges from sandy field roads, through forest paths with visible tree roots, to difficult rocky slopes.

Difficult terrain, physical and psychological exhaustion, bicycle malfunction, distraction or wrong assessment of situation during fast cycling on difficult terrain $[9,12]$, and the desire to win, can lead to serious injuries in cyclists during training or competitions. Overuse injuries are also common, and can comprise $55-85 \%$ of all injuries $[7,16]$. Lareau et al. [12] nie odnotowali znaczących różnic w typach urazów podczas badania zawodników XC oraz MX. Authors studying the incidence of cycling-related injuries report that approx. $2-30 \%$ of the studied groups were women $[9,17]$.

Najczęścieszymi lokalizacjami urazów ostrych w kolarstwie jest: ankle, shoulder (clavicle bone)/arm, knee $[7,8,9]$. However, knee joint, cervical and lumbar regions of the spine are the most common localizations of overuse injuries $[7,18]$.

Mountain cycling exposes the human body to constant vibrations of various amplitude which can lead to adverse health effects, especially pain in intercarpal articulations and spine $[14,19,20]$. Low back pain is a common overuse injury among cyclists, and many authors [21] attribute this to a longlasting inclination of cyclists. Inclination can lead to longer intervertebral stress, intradiscal pressure or viscoelastic deformation of lumbar tissues, and eventually to pain [21]. Muyor et al. [21] reported spinal adaptive changes in cyclists: thoracic hyperkyphosis in standing (smaller in sitting) and higher anterior pelvic tilt. Long-lasting inclination occurring during cycling can contribute to pain in the cervical curve (hyperlordosis in watching the terrain) [18]. Srinivasan et al. [22] showed a significant difference in spinal muscle fatigue in people depending on whether or not they experienced pain.

The mean BMI of the study subject shows that their body mass is normal relatively to their height (Tab. 2). A large number of hours spent in training helps in maintaining a healthy body weight (Tab. 2). However, the incidence of injury increases along with the number of hours spent in training [7]. The results of the presented study confirm this only with regard to sacral spine pain.

Data analysis demonstrated that age, BMI and cycling training experience have a significant effect on the incidence of pain in individual spine segments. Increased body mass, age above the average, and longer training experience, all support the hypothesis that overuse injuries are a cause of spine pain. Wang et al. [23] and Heir et al. [24] disagree and report no correlation between height, weight, age and injuries of the musculoskeletal system. However, these studies were carried out with police officers and soldiers as study subjects.

Knee joint injuries were reported by 66 subjects, which makes them the most common type of injury. In the current study, no correlations were founsd between age, weight, height, BMI, or the time spent on a bicycle and the incidence of pain. Lower extremity injuries can be caused by individual biomechanical factors and a relationship between symmetrical bicycle structure-asymmetrical body of a cyclist $[25,26]$. Small elasticity of the muscle-ligament system or differences in the length of the legs can cause of iliotibial band syndrome in the shorter leg and posterior knee pain $[22,25,27]$. Medial knee pain can be caused by a flat foot and/ or the internal rotation of the foot [25]. The most frequently described cause of anterior knee pain is patellofemoral pain syndrome [27]. The trajectory of patella movement during extension is modified by the joint's surfaces and the tension of active stabilizers - the vastus lateralis and vastus medialis muscles [28]. Dieter et al. noticed that people with patellofemoral pain syndrome have a different thigh muscle activation time than the control group, and that these muscles are responsible for the syndrome [29].

As the results of the current study show, heavily overloaded joints of the athletes are prone to injuries. It is important to prepare oneself before any physical activity by performing a warm-up, which often gets neglected or poorly executed. The results show that stretching after cycling is of great importance. There was a significant correlation between stretching and the incidence of knee pain. This correlation can be easily explained. As the questionnaire showed, each participant with knee pain started stretching out of fear for their knee. Unfortunately, the results do not show whether the incidence of pain was reduced after the introduction of stretching.

In order to avoid future injuries, it is not only the style of riding and its intensity that have to be modified, but also saddle position and angle, handlebars position, frame size and pedal system $[13,17]$. Warm-up and stretching after cycling are recommended, because if all the anomalies are not eradicated, the pain will return.

Limitations of research. Despite the fact that the number of studies on injuries in cycling is increasing, it is difficult to relate to their results because each author selects groups in their own way. Some rely on questionnaires for professional cyclists, some rely on questionnaires sent through the post, others rely on data from emergency rooms and orthopedic clinics. In this study, a questionnaire was used to study amateur cyclists participating in races because it was believed that it reflected the actual state of affairs the most accurately.

While filling out the questionnaire, it was noticed that not everyone was willing to mention their pain experiences because it is considered normal in this sport or their age. This phenomena can result in some pain experiences remaining unreported. The results of the questionnaire did not show whether stretching reduces the incidence of pain in people experiencing it.

\section{CONCLUSIONS}

Cyclists cite knee joint and lumbar spine as the locations most commonly affected by pain.

1. Variables such as age, weight, height, BMI, training experience and the number of hours in training per week did not have a significant influence of the incidence and the localization of pain in the lower extremities, but the influence was present in the case of spine pain.

2. Attention must be paid to the form and the duration of warm-up and stretching.

3. Modifications in the technique of riding a bicycle and in the bicycle itself can lead to reduced injury incidence.

\section{Conflict of Interests}

The authors declare that there is no conflict of interests regarding the publication of this paper. 


\section{REFERENCES}

1. Zhang WH, Xue P, Yao MY, Chang HM, Wu Y, Zhang L. Prevalence of Metabolic Syndrome and Its Relationship with Physical Activity in Suburban Beijing. China. Ann Nutr Metab. 2014; 63(4): 298-304. [Epub ahead of print]

2. Orsini N, Bellocco R, Bottai M, Pagano M, Andersson SO, Johansson JE, Giovannucci E, Wolk A. A prospective study of lifetime physical activity and prostate cancer incidence and mortality. Br J Cancer. 2009; 101(11): 1932-1938. doi: 10.1038/sj.bjc.6605404.

3. GUS. Uczestnictwo Polaków w sporcie i rekreacji ruchowej w 2012 r., Warszawa 2013 r. http://www.stat.gov.pl/cps/rde/xbcr/gus/KTS uczestnictwo_polakow_w_sporcie_2012.pdf (access: 2014.04.08)

4. Macdermid PW, Fink PW, Stannard SR.Transference of 3D accelerations during cross country mountain biking. J Biomech. 2014; 47(8): 1829_ 1837. doi: 10.1016/j.jbiomech.2014.03.024.

5. Faiss R, Praz M, Meichtry A, Gobelet C, Deriaz O. The effect of mountain bike suspensions on vibrations and off-road uphill performance. J Sports Med Phys Fitness. 2007;47(2):151-158.

6. Thompson MJ, Rivara FP. Bicycle-related injuries. Am Fam Physician. 2001; 63(10):2007-2014.

7. Fordham S, Garbutt G, Lopes P. Epidemiology of injuries in adventure racing athletes. Br J Sports Med. 2004; 38(3): 300-303.

8. Silberman MR. Bicycling injuries. Curr Sports Med Rep. 2013; 12(5): 337-345. doi: 10.1249/JSR.0b013e3182a4bab7.

9. Gaulrapp H, Weber A, Rosemeyer B. Injuries in mountain biking. KneeSurg Sports Traumatol Arthrosc. 2001; 9(1): 48-53.

10. Raymond CH, Joseph K-F, Gabriel YF. Muscle recruitment pattern in cycling: a review. Physical Therapy in Sport 2005; 6: 89-96.

11. Aleman KB, Meyers MC. Mountain biking injuries in children and adolescents. Sports Med. 2010 Jan 1; 40(1): 77-90. doi: 10.2165/11319640000000000-00000.

12. Lareau SA, McGinnis HD. Injuries In Mountain Bike Racing: Frequency of Injuries In Endurance Versus Cross Country Mountain Bike Races Wilderness \& Environmental Medicine, 2011; 22(3): 222-227.e3

13. Silberman MR, Webner D, Collina S, Shiple BJ. Road bicycle fit. Clin J Sport Med. 2005 Jul; 15(4): 271-6.

14. Aleman KB, Meyers MC. Mountain biking injuries in children and adolescents. Sports Med. 2010; 40(1): 77-90. doi: 10.2165/11319640000000000-00000.
15. Sport Challenge http://www.sportchallenge.cz/pl/zavody/ vysledky?rok=all (access: 2014.04.08)

16. Norvell DC, Dettori NJ. Non-Traumatic Bicycle Injuries. Sports Med. 2006: 36(1): 7-18

17. Rivara FP, Thompson DC, Thompson RS. Epidemiology of bicycle injuries and risk factors for serious injury. Inj Prev. 1997; 3(2): 110-114.

18. Asplund C, Webb C, Barkdull T. Neck and back pain in bicycling. Curr Sports Med Rep. 2005; 4(5): 271-274.

19. Faiss R, Praz M, Meichtry A, Gobelet C, Deriaz O. The effect of mountain bike suspensions on vibrations and off-road uphill performance. J Sports Med Phys Fitness. 2007; 47(2): 151-158.

20. Bovenzi M, Hulshof CT. An updated review of epidemiologic studies on the relationship between exposure to whole-body vibration and low back pain (1986-1997). Int Arch Occup Environ Health. 1999; 72(6): 351-365.

21. Muyor JM, López-Miñarro PA, Alacid F. Spinal posture of thoracic and lumbar spine and pelvic tilt in highly trained cyclists. J Sports Sci Med. 2011; 10(2): 355-361.

22. Holmes JC, Pruitt AL, Whalen NJ. Iliotibial band syndrome in cyclists. Am J Sports Med. 1993; 21(3): 419-424.

23. Wang X, Wang PS, Zhou W. Risk factors of military training-related injuries in recruits of Chinese People's Armed Police Forces. Chin J Traumatol. 2003; 6(1): 12-17.

24. Heir T, Eide G. Age, body composition, aerobic fitness and health condition as risk factors for musculoskeletal injuries in conscripts. Scand J MedSci Sports. 1996; 6(4): 222-227.

25. Asplud Ch, St. Pierre P. Knee Pain and Bicycling. The Physician and Sportsmedicine 2004; 32(4): 1-11.

26. Cohen GC. Cycling injuries. Can Fam Phys. 1993; 39: 628-632.

27. Cosca DD, Navazio F. Common problems in endurance athletes. Am Fam Physician. 2007; 76(2): 237-244

28. Wilis FB, Burkhardt EJ, Walker JE, Johnson MA, Spears TD. Preferential vastus medialis oblique activation achieved as a treatment for knee disorders. Jurnal of Strength and Conditioning Research 2005; 19(2): 286-291.

29. Dieter BP, McGowan CP, Stoll SK, Vella CA. Muscle activation patterns and patellofemoral pain in cyclists. Med Sci Sports Exerc. 2014; 46(4): 753-761. doi: 10.1249/MSS.0000000000000153. 